\title{
Partial purification and characterization of the bacteriocin produced by Propionibacterium jensenii B1264
}

\author{
Priya Ratnam ${ }^{\mathrm{a}}$, Susan F. Barefoot ${ }^{\mathrm{a}, \mathrm{b} *}$, Lisa D. Prince ${ }^{\mathrm{a}}$, \\ Ashby B. Bodine ${ }^{\mathrm{c}}$, Linda H. McCaskilla \\ a Department of Microbiology and Molecular Medicine, Clemson University, \\ 124 Long Hall, Clemson SC 29634, USA \\ ${ }^{\mathrm{b}}$ Department of Food Science and Human Nutrition, Clemson University, \\ 224 Poole Ag Centre, Clemson SC 29634, USA \\ ${ }^{\mathrm{c}}$ Department of Animal and Veterinary Sciences, Clemson University, \\ 129 Poole Ag Centre, Clemson SC 29634, USA
}

\begin{abstract}
Thirteen dairy propionibacteria were screened for catalase-insensitive, protease-sensitive inhibition of various Gram-positive and Gram-negative bacteria. Production of bacteriocin-like agents was identified in 8 of these cultures. The bacteriocin produced by Propionibacterium jensenii B1264 inhibited closely related propionibacteria and lactic acid bacteria and was bactericidal to Lactobacillus delbrueckii subsp. lactis ATCC 4797. It was produced in sodium lactate broth cultures during stationary phase; maximum activity was detected after $10 \mathrm{~d}$ of growth but only after 10 -fold concentration of culture supernatants. The bacteriocin was precipated by ammonium sulphate at $70 \%$ saturation. The ammonium sulphate-concentrated, dialyzed bacteriocin was stable to $0.1-1.0 \mathrm{~mol} \cdot \mathrm{L}^{-1}$ $\mathrm{NaCl}, 0.1-2.0 \%$ SDS, $4 \mathrm{~mol} \cdot \mathrm{L}^{-1}$ urea, $100{ }^{\circ} \mathrm{C}(60 \mathrm{~min}), \mathrm{pH}$ 2-10 and organic solvents (methanol, ethanol and isopropanol at $0-50 \%$ ). Batch anion exchange chromatography ( $\mathrm{pH} 6.5)$ of the bacteriocin yielded $101 \%$ activity and 15 -fold increased purity. Flat bed analytical isoelectric focussing showed that the isoelectric point was between $\mathrm{pH} 3$ and 3.5. SDS-PAGE yielded an estimated molecular mass between 6 and $9 \mathrm{kDa}$. The evidence suggests that this anionic bacteriocin is unique. (C) Inra/Elsevier, Paris.
\end{abstract}

\section{Propionibacterium jensenii / bacteriocin / propionibacteria}

Résumé - Purification partielle et caractérisation de la bactériocine produite par Propionibacterium jensenii B1264. Treize bactéries propioniques ont été examinées pour leur capacité catalase-insensible et protéase-sensible à inhiber différentes bactéries gram-positives ou gram-négatives. La production d'agents de type bactériocine a été identifiée dans huit des cultures. La bactériocine produite par Propionibacterium jensenii B1264 avait une activité inhibitrice sur les propionibactéries

Oral communication at the 2nd Symposium on Propionibacteria, Cork, Ireland, June 25-27, 1998. *Correspondence and reprints. SBrft@Clemson.edu 
proches et des bactéries lactiques et une activité bactéricide envers Lactobacillus delbrueckii subsp. lactis ATCC 4797. Elle était produite en bouillon de lactate de sodium pendant la phase stationnaire ; l'activité maximale était détectée après $10 \mathrm{j}$ mais seulement avec une concentration par dix de surnageants. La bactériocine était précipitée au sulphate d'ammonium à une saturation à $70 \%$. La bactériocine concentrée au sulfate d'ammonium et dialysée était stable de $0,1-1,0 \mathrm{~mol} \cdot \mathrm{L}^{-1}$ de $\mathrm{NaCl}$, $0,1 \%$ à $2,0 \% \mathrm{SDS}, 4 \mathrm{~mol} \cdot \mathrm{L}^{-1}$ urée, $100^{\circ} \mathrm{C}(60 \mathrm{~min})$, de $\mathrm{pH} 2$ à 10 et dans les solvants organiques (méthanol, éthanol et isopropanol à 0 à $50 \%$ ). La chromatographie d'échange d'anions en batch $(\mathrm{pH} 6,5)$ de la bactériocine permettait d'obtenir une activité et une pureté accrue par un facteur de quinze. La focalisation isoélectrique analytique en couche mince donnait un point isoélectrique entre $\mathrm{pH} 3$ et 3,5. La masse moléculaire obtenue par SDS-PAGE se situait entre 6 et $9 \mathrm{kDa}$. Les données suggèrent que cette bactériocine anionique est unique. (C) Inra/Elsevier, París.

\section{Propionibacterium jensenii / bactériocine / propionibactérie}

\section{INTRODUCTION}

Dairy or classical propionibacteria include Propionibacterium freudenreichii, $P$. thoenii, $P$. acidipropionici and $P$. jensenii, and have been isolated from cheese, milk products, soil, olives and silage fermentations [3]. Their industrial importance lies in their production of Swiss cheese flavor and 'eyes', vitamin B $_{12}$ and inhibitors, including propionic acid and bacteriocins (antimicrobial proteins).

Only two dairy propionibacteria bacteriocins have been characterized to date. Propionicin PLG-1 is produced by $P$. thoenii P127 [11, 12] and inhibits Gram-positive bacteria including $P$. thoenii, $P$. acidipropionici, $P$. jensenii and lactic acid bacteria, Gram-negative bacteria (Pseudomonas, Vibrio, and Campylobacter spp. and Escherichia coli), and selected yeasts and molds [11]. It is sensitive to protease, pronase $\mathrm{E}$, pepsin, trypsin, and $\alpha$-chymotrypsin, insensitive to catalase, and lipase but stable from $\mathrm{pH} 3$ to 9 and to temperatures $\leq 85^{\circ} \mathrm{C}$. The bacteriocin is produced in late stationary phase in agar and broth cultures [12]. Its production has been examined in both batch $[9,12]$ and fed-batch [16] fermentations; five times more activity is produced in cultures grown at $\mathrm{pH} 7.0$ in a $3: 1$ beet molasses:corn steep liquor medium than in sodium lactate broth. Propionicin PLG-1 is bactericidal to
P. acidipropionici P5 without causing cell lysis; it kills $99.6 \%$ of indicator cells within $60 \mathrm{~min}$ [12]. Lyon and Glatz [12] purified propionicin PLG-1 to homogeneity by sequential ammonium sulphate precipitations first at $40 \%$ and then at $60 \%$, ion exchange chromatography on carboxymethyl cellulose and preparative isoelectric focussing. SDS-PAGE analysis of the purified bacteriocin yielded a single $10-\mathrm{kDa}$ band. In preparation for $\mathrm{N}$-terminal sequencing, Paik and Glatz [15] obtained larger quantities of propionicin PLG-1 by ammonium sulphate precipitation, ion exchange chromatography, and reversed-phase highperformance liquid chromatography on a $\mathrm{C}_{18}$ column. Composition analysis yielded a molecular mass of $9328 \mathrm{Da}$ and a high proportion $(42 \%)$ of hydrophobic amino acids [15].

Jenseniin $\mathrm{G}$ is a bacteriocin produced by P. thoenii (jensenii) P126 [6]. It inhibits dairy propionibacteria including $P$. jensenii and $P$, acidipropionici, Lactobacillus delbrueckii subsp. lactis ATCC 4797, Lb. helveticus, Lactococcus lactis subsp. cremoris and lactis [6], several strains of $L b$. delbrueckii subsp. bulgaricus and Streptococcus thermophilus [19] and Clostridium botulinum types $\mathrm{A}, \mathrm{B}$, and $\mathrm{E}$ spores (unpublished data). It is sensitive to proteinase $\mathrm{K}$, pronase E, type 14 protease and insensitive to catalase. Unlike propionicin PLG-1 [11], 
jenseniin $\mathrm{G}$ is stable at $100{ }^{\circ} \mathrm{C}$ for $15 \mathrm{~min}$ and to $\mathrm{pH}$ values between 3 and 12 . Jenseniin $\mathrm{G}$ is bacteriostatic to $P$. acidipropionici $\mathrm{P5}$ and bactericidal to $L b$. delbrueckii subsp. lactis ATCC 4797. Activity is detected only in 50-to 100-fold concentrated 10 -d old culture supernatants [6].

Because only two bacteriocins have been confirmatively identified in dairy propionibacteria, we examined 13 additional cultures for catalase-insensitive and proteasesensitive inhibition. One culture $P$. jensenii B1264 was selected for further study. Characteristics identified for the responsible antagonist were consistent with its classification as a bacteriocin.

\section{MATERIALS AND METHODS}

\subsection{Bacterial cultures and media}

Propionibacterium species B1262, B1263, B1264, B1265, B1 267 and B1268 were obtained from the All Union Collection of Microorganisms, Pushchino, Moscow Region, Russia. $P$. thoenii P127, $P$. thoenii (jensenii) P126 and $P$. acidipropionici $\mathrm{P} 5$ were graciously provided by Dr B.A. Glatz, Iowa State University, Ames, USA. Lactobacillus plantarum strains 965, MOP 3 and MOP 7 were provided by Dr M. Daeschel, North Carolina State University, Raleigh, USA. Lb. plantarum CSCC 2901 was obtained from Commonwealth Scientific and Industrial Research Organisms, Victoria, Australia. P. shermanii strains MNS and KFA were obtained from Dr V.L. Crow, New Zealand Dairy Research Institute. $P$. acidipropionici CRL 756 and $P$. freudenreichii subsp. shermanii CRL 757 were obtained from Dr G. Oliver, National University of Tucuman, Argentina. P. jensenii ATCC 4868, $P$. freudenreichii ATCC 6207 and all other cultures were from the Clemson University Food Microbiology Culture Collection, USA.

Dairy propionibacteria were propagated $(1 \%$ $\mathrm{v} / \mathrm{v}$ inoculum) in sodium lactate broth (NLB), consisting of $1 \% \mathrm{w} / \mathrm{v}$ trypticase soy broth without dextrose (BBL Microbiology Systems, Cockeysville, MD, USA), 1 \% w/v yeast extract (Difco Laboratories, Detroit, MI, USA) and $1 \%$ sodium lactate syrup ( $60 \%$ w/w, Fisher Scientific Co., Pittsburgh, PA. USA) in distilled water [7] at $32{ }^{\circ} \mathrm{C}$ under flowing $\mathrm{CO}_{2}\left(0.4 \mathrm{~L} \cdot \mathrm{h}^{-1}\right)$. Sodium lactate agar (NLA) and soft NLA were prepared by adding $1.8 \% \mathrm{w} / \mathrm{v}$ and $0.75 \% \mathrm{w} / \mathrm{v}$ agar (BBL) to NLB, respectively. $L b$. delbrueckii subsp. lactis ATCC 4797 and other lactobacilli were propagated in Lactobacilli MRS broth (MRS; Difco) for $16 \mathrm{~h}$ at $37^{\circ} \mathrm{C}$ under flowing $\mathrm{CO}_{2}\left(0.4 \mathrm{~L} \cdot \mathrm{h}^{-1}\right)$. Indicator lactococci were propagated at $32{ }^{\circ} \mathrm{C}$ in M-17 broth (BBL). Agar media other than NLA contained $1.5 \%$ w/v agar; soft agars contained $0.75 \%$ agar w/v. Populations of lactobacilli were determined by plating on MRS agar $\left(37^{\circ} \mathrm{C}, 48 \mathrm{~h}\right)$; propionibacteria were enumerated by plating on NLA $\left(32{ }^{\circ} \mathrm{C}, 5 \mathrm{~d}\right)$. Frozen stock cultures were maintained at $-70^{\circ} \mathrm{C}$ in the appropriate growth medium containing $10 \%$ glycerol. Working cultures were prepared from stock cultures by propagating twice in the appropriate growth medium. Lactobacilli [14] and propionibacteria [4] were identified by biochemical tests and purity was assessed by streaking and microscopic observation.

\subsection{Bacteriocin activity and detection assays}

Activity was determined by a critical point dilution method [1]. Pre-poured MRS agar plates were overlaid with $5 \mathrm{~mL}$ of soft MRS agar, seeded with $10 \mu \mathrm{L}$ of a 16 to $24 \mathrm{~h}$ MRS broth culture of $L b$. delbrueckii subsp. lactis ATCC 4797 (final population, $10^{5}$ to $10^{6} \mathrm{cfu} \cdot \mathrm{L}^{-1}$ ) and $10 \mu \mathrm{L}$ aliquots of serial two-fold dilutions of bacteriocin were applied. Activity was defined as the reciprocal of the highest dilution showing zones of inhibition and was expressed in activity units (AU) per millilitre [8]. Activity was also detected by spotting $10-\mu \mathrm{L}$ aliquots of putative bacteriocin preparations on the lawns.

\subsection{Preparation of crude bacteriocin}

P. jensenii B1264 (1\% inoculum) was added to NLB (16 L) and held at $32{ }^{\circ} \mathrm{C}$ for $10 \mathrm{~d}$ under flowing $\mathrm{CO}_{2}\left(0.4 \mathrm{~L} \cdot \mathrm{h}^{-1}\right)$. Cells were removed by centrifugation at $6300 \mathrm{~g}$ for $30 \mathrm{~min}$ at $4{ }^{\circ} \mathrm{C}$ followed by filtration through a $0.45-\mathrm{mm}$ pore-size membrane filter (Gelman, Ann Arbor, MI, USA). Ammonium sulphate was added slowly with constant stirring to filtered supernatants to $70 \%$ or $80 \%$ saturation and held overnight at $4{ }^{\circ} \mathrm{C}$, Pelleted proteins were centrifuged at $19600 \mathrm{~g}$ for $30 \mathrm{~min}$ at $4{ }^{\circ} \mathrm{C}$, resuspended in $25 \mathrm{~mL}$ $0.1 \mathrm{~mol} \cdot \mathrm{L}^{-1}$ sodium phosphate buffer $(\mathrm{pH} 6.4)$ 
and dialyzed against the same buffer ( 4 changes, $4 \mathrm{~L}$ each, $12 \mathrm{~h}$ per dialysis) in 3500 molecularweight-cut-off (MWCO) dialysis tubing (SpectraPor number 3, Spectrum Medical Industries, Los Angeles, CA, USA).

\subsection{Stability tests}

Urea was added to crude bacteriocin ( $\mathrm{pH} 6.5$ ) or partially purified bacteriocin in sodium phosphate buffer $\left(0.1 \mathrm{~mol} \cdot \mathrm{L}^{-1}, \mathrm{pH} 6.0\right)$ to $4 \mathrm{~mol} \cdot \mathrm{L}^{-1}$ final concentration and held for $0,30,60,120$, 180 or $240 \mathrm{~min}$ at 20 to $25^{\circ} \mathrm{C}$. Crude bacteriocin ( $\mathrm{pH} 6.5$ ) was treated by holding in a waterbath at $100{ }^{\circ} \mathrm{C}$ for $0,15,30,45,60$ or $120 \mathrm{~min}$. SDS was added to crude bacteriocin ( $\mathrm{pH} 6.5)$ or partially purified bacteriocin in sodium phosphate buffer $\left(0.1 \mathrm{~mol} \cdot \mathrm{L}^{-1}, \mathrm{pH} 6.0\right)$ to final concentrations of $0,0.1,0.4,0.6,0.8,1.0$ and $2.0 \%$. Activity of preparations was detected using lawns of the indicator $L b$. delbrueckii subsp. lactis ATCC 4797.

\subsection{Analytical isoelectric focussing}

Analytical isoelectric focussing [5] was conducted using a $\mathrm{pH} 3$ to 7 gradient agarose gel (FMC BioProducts, Rockland, ME, USA). Focussing was at $10 \mathrm{~W}$ constant power, I $500 \mathrm{~V}$ maximum for $45 \mathrm{~min}$. Focussed gels were halved. One half was overlaid with soft MRS agar containing the indicator strain, $L b$. delbrueckii subsp. lactis ATCC 4797 , incubated for $24 \mathrm{~h}$ and examined for inhibition. The other half was silverstained per the manufacturer's instructions (BioRad Laboratories, Richmond, CA, USA).

\subsection{Batch anion exchange chromatography}

The anion exchanger, Bio-Rad Macro-Prep Q (typically 6-mL packed wet resin) was prepared by washing five times with $0.1 \mathrm{~mol} \cdot \mathrm{L}^{-1}$ sodium phosphate buffer ( $\mathrm{pH} 6.0$ ), centrifuging at $6300 \mathrm{~g}$ for $10 \mathrm{~min}$ and decanting as supernatants. Crude jenseniin P (typically $1 \mathrm{~mL}, 800 \mathrm{AU} \cdot \mathrm{mL}^{-1}$ ) was dialyzed $\left(24 \mathrm{~h}\right.$ at $\left.4{ }^{\circ} \mathrm{C}\right)$ in $3500 \mathrm{MWCO}$ tubing against the same buffer, mixed with the resin and held with gentle stirring for $30 \mathrm{~min}$. The resin and adsorbed protein were washed repeatedly ( 5 to 6 times) with $0.1 \mathrm{~mol} \cdot \mathrm{L}^{-1}$ sodium phosphate buffer containing $0.1 \mathrm{~mol} \cdot \mathrm{L}^{-1} \mathrm{NaCl}$. All wash- ings were combined, concentrated by speed vacuum and assayed for activity and protein.

\subsection{SDS-PAGE analysis and protein assays}

Electrophoresis was performed on 4 to $20 \%$ gradient SDS-PAGE gels (Bio-Rad Ready gels) using the protocol of Laemmli [10] at constant current $(200 \mathrm{~mA}$ ) for $60 \mathrm{~min}$. Half of the gel was washed in distilled water for $60 \mathrm{~min}$ and overlaid with soft MRS agar $\left(10 \mathrm{~mL}^{-1}\right)$ containing the indicator strain, $L b$. delbrueckii subsp. lactis ATCC 4797. The other half was fixed and silver-stained. Protein was determined by the Bradford method [2] per the manufacturer's instructions (Bio-Rad) using bovine serum albumin as standard or by ultraviolet absorption at $280 \mathrm{~nm}$ [17] using serum immunoglobulin $\mathrm{G}$ as standard.

\section{RESULTS}

\subsection{Identification of bacteriocin activity}

Thirteen dairy propionibacteria were examined for bacteriocin production. Eight cultures, Propionibacterium strains B1262, B1263, B1264, B1265, B1267 and B1268, $P$. jensenii ATCC 4868 and $P$. freudenreichii ATCC 6207 showed catalase-insensitive, protease-sensitive antagonism. Inhibitory activity was limited to lactobacilli, lactococci, and some propionibacteria (table I). P. acidipropionici ATCC 25562 and $P$. freudenreichii subsp. shermanii strains CRL 756, CRL 757, MNS and KFA did not elicit protease-sensitive inhibition of the indicator strains. No propionibacteria produced bacteriocin-like activity against 15 Gram-positive and 14 Gram-negative bacteria including staphylococci, Bacillus cereus, Listeria monocytogenes, Escherichia coli, Salmonella typhimurium and Vibrio parahaemolyticus.

An unusual pattern of inhibition was noted for the antagonists produced by $P$. jensenii B 1264, $P$. jensenii ATCC 4868 and $P$. freudenreichii ATCC 6207 in NLA 
Table I. Bacteriocin-like inhibition by dairy propionibacteria.

Tableau I. Inhibition de type bactériocine par les bactéries propioniques laitières.

\begin{tabular}{|c|c|c|c|c|c|c|c|c|}
\hline \multirow[b]{2}{*}{ Indicator strains ${ }^{\mathrm{b}}$} & \multicolumn{8}{|c|}{ Putative producer propionibacteria ${ }^{a}$} \\
\hline & B1264 & B1262 & B1263 & B 1265 & B1267 & B1268 & $\begin{array}{c}\text { ATCC } \\
4868\end{array}$ & $\begin{array}{c}\text { ATCC } \\
6207\end{array}$ \\
\hline Propionibacterium jensenii B1264 & $\operatorname{yes}^{\mathrm{c}}$ & no & yes & no & no & no & & \\
\hline P. acidipropionici $\mathrm{P} 5$ & yes & no & yes & no & yes & no & no & yes* \\
\hline P. thoenii (jensenii) P126 & yes & no & yes & yes & no & no & no & no \\
\hline P. thoenii P127 & yes & no & yes & no & no & no & no & no \\
\hline Lactobacillus acidophilus ATCC 4356 & yes & no & no & no & no & no & & \\
\hline Lb. casei ATCC 393 & no & yes & no & yes & no & no & yes* & yes* \\
\hline Lb. casei 7469 & no & no & no & yes & no & no & & \\
\hline Lb. delbrueckii subsp. delbrueckii ATCC 9649 & yes & no & yes & no & yes & yes & yes* & yes* \\
\hline Lb. delbrueckii subsp. bulgaricus NCDO 1489 & yes & yes & yes & no & no & no & no & no \\
\hline Lb. delbrueckii subsp. lactis ATCC 4797 & yes & no & yes & no & no & no & yes* & yes* \\
\hline Lb. helveticus ATCC 15009 & yes** & no & no & yes & yes & no & yes* & yes* \\
\hline Lb. plantarum $\operatorname{CSCC} 2901$ & yes** & no & no & no & no & no & & \\
\hline Lb. plantarum PI 549 & yes** & no & no & no & no & no & & \\
\hline Lactococcus lactis subsp. lactis $\mathrm{C} 2$ & yes** & no & yes & no & no & no & & \\
\hline
\end{tabular}

a Protease-sensitive, catalase-insensitive inhibition was assessed by a deferred agar spot assay. Producer cultures were spotted on NLA plates and incubated for $5 \mathrm{~d}$ at $32{ }^{\circ} \mathrm{C}$ under flowing $\mathrm{CO}_{2}\left(0.4 \mathrm{~L} \cdot \mathrm{h}^{-1}\right)$. Plates were overlaid with soft agars seeded with $10 \mu \mathrm{L}$ of indicator culture $\left(\sim 10^{7} \mathrm{CFU} \cdot \mathrm{mL}^{-1}\right)$ and incubated appropriately for development of lawns. ${ }^{b}$ Abbreviations: ATCC, American Type Culture Collection, Rockville, MD, USA; NCDO, National Collection of Dairy Organisms (currently National Collection of Food Bacteria), AFRC Institute of Food Research, Reading, England; YIT, Yakult Institute for Microbiology Research, Tokyo, Japan; PI, Presque Isle Cultures, Presque Isle, PA, USA. ' Legend: yes, bacteriocin-like inhibition; yes ${ }^{*}$, bacteriocin-like inhibition that increased after protease treatment; yes ${ }^{* *}$, bacteriocin-like inhibition, but only after protease treatment; no, no bacteriocin-like inhibition.

a $\mathrm{L}$ 'inhibition protéase-sensible et catalase-insensible était testée indépendamment sur agar, Les cultures productrices étaient mises en évidence sur plaque d'agar de lactate de sodium et incubées $5 \mathrm{j}$ à $32{ }^{\circ} \mathrm{C}$ sous flux de $\mathrm{CO}_{2}\left(0,4 \mathrm{~L} \cdot \mathrm{h}^{-1}\right)$. Les plaques étaient recouvertes d'agar mou ensemencé avec $10 \mu \mathrm{L}$ de culture indicatrice $\left(\sim 10^{7} \mathrm{UFC} . \mathrm{mL}^{-1}\right)$ et incubées de façon appropriée pour le développement des tapis bactériens. ${ }^{b}$ Abbréviations : voir légende anglaise. ${ }^{\mathrm{c}}$ Légende : yes, inhibition de type bactériocine ; yes*, inhibition de type bactériocine augmentant après traitement à la protéase ; yes**, inhibition de type bactériocine mais uniquement après traitement à la protéase ; no, pas d'inhibition de type bactériocine. 
cultures (table I). Application of pronase $\mathrm{E}$ and type XIV proteinase near $P$. jensenii B1264 resulted in crescent-shaped inhibition zones (figure 1) at the application sites and broadened its inhibitory spectrum to Lactococcus lactis subsp. lactis $\mathrm{C} 2$, Lactobacillus helveticus ATCC 15009, Lb. plantarum CSCC 2901 and Lb. plantarum PI 549 . In the absence of protease, agar cultures of $P$. jensenii ATCC 4868 inhibited indicator lactobacilli and agar cultures of P. freudenreichii ATCC 6207 inhibited propionibacteria and lactobacilli. Protease treatment alone did not affect the lawns; thus, inhibition was not due to the enzyme. Combination of the soluble inhibitors produced by $P$. jensenii ATCC 4868 and P. freudenreichii ATCC 6207 with pronase immediately before their application to indicator lawns increased inhibitory activity. Longer treatment of soluble inhibitors with protease ( $\geq 2 \mathrm{~min}$ ) before applying them to indicator lawns completely destroyed the activity. The expanded spectrum could be due to limited proteolysis of either the antagonists or other bacterial products diffusing through the agar medium. The protease-sensitive antagonist produced by $P$. jensenii B1264 had the broadest inhibitory spectrum and was examined further.

\subsection{Production and mode of action}

Batch cultures of $P$. jensenii B1264 were examined for inhibitory activity. Activity was detected only during late stationary phase producer growth and then only in

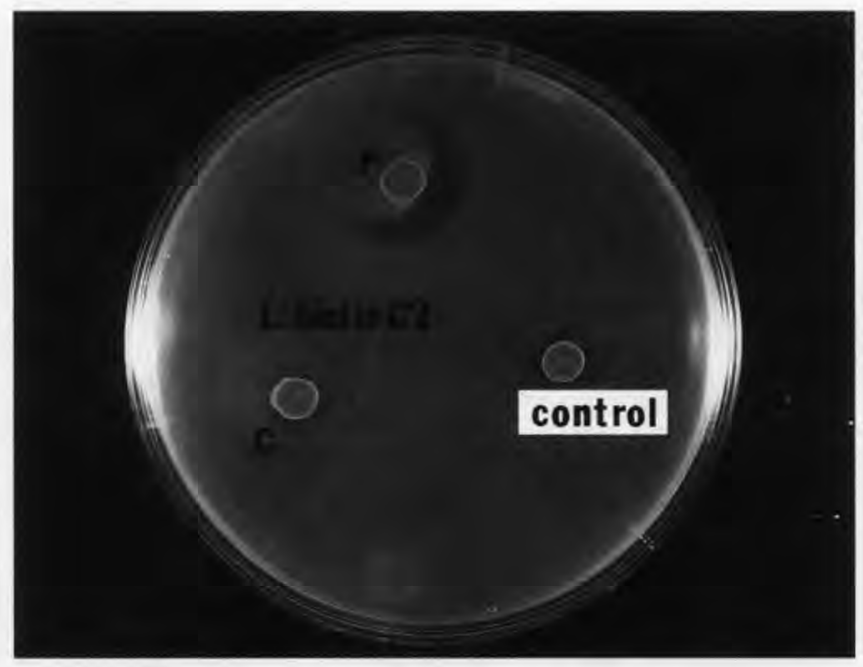

Figure 1. Protease potentiation of inhibitory activity of Propionibacterium jensenii B1264. The enzymes pronase $\mathrm{E}\left(\mathbf{P} ; 15 \mu \mathrm{L}, 10 \mathrm{mg} \cdot \mathrm{mL}^{-1}\right)$ and catalase $\left(\mathbf{C} ; 15 \mu \mathrm{L}, 10 \mathrm{mg} \cdot \mathrm{mL}^{-1}\right)$ were applied to the left of 5-d, sodium lactate agar producer cultures. No enzyme was applied at the producer culture designated 'control'. Cultures were overlaid with Lactococcus lactis $\mathrm{C} 2(10 \mu \mathrm{L}$ overnight culture per $5 \mathrm{~mL}$ soft tempered $\mathrm{M}-17$ ) and held overnight at $32{ }^{\circ} \mathrm{C}$ under flowing $\mathrm{CO}_{2}$ for development of the lawn.

Figure 1. Activation par la protéase de l'activité inhibitrice de Propionibacterium jensenii B1264. Les enzymes pronase $E\left(\mathbf{P} ; 15 \mu \mathrm{L}, 10 \mathrm{mg} \cdot \mathrm{mL}^{-1}\right)$ et catalase $\left(\mathbf{C} ; 15 \mu \mathrm{L}, 10 \mathrm{mg} \cdot \mathrm{mL}^{-1}\right)$ ont été déposées sur la partie gauche des plaques d'agar au lactate de sodium de cultures productrices à $5 \mathrm{j}$. Aucune enzyme n'était déposée pour la culture productrice désignée par "control ». Les cultures étaient recouvertes avec Lactococcus lactis $\mathrm{C} 2$ (10 $\mu \mathrm{L}$ d'une culture d'une nuit sur $5 \mathrm{~mL}$ de milieu M17 ramolli) et maintenu 1 nuit à $32^{\circ} \mathrm{C}$ sous flux de $\mathrm{CO}_{2}$ pour le développement des tapis bactériens. 
2-fold to 16-fold concentrated culture filtrates. There was some evidence that cell lysis was occurring and that the bacteriocin could be released from the intracellular environment but this has not been explored further as yet. Maximum production $\left(200 \mathrm{AU} \cdot \mathrm{mL}^{-1}\right.$ ) was observed at day 10 and decreased thereafter (figure 2). Most bacteriocins are bactericidal to sensitive cells [18]. Treatment of cells of $L b$. delbrueckii subsp. lactis ATCC 4797 cells with the antagonist produced by $P$. jensenii B1264 reduced the viability of the lactobacilli by $90 \%$ within 60 min (figure 3). Turbidity dropped by 0.1 absorbance units after $75 \mathrm{~min}$; therefore, lysis occurred only after indicator cell death. The data suggest a bactericidal mode of action.

\subsection{Stability}

Effects of various enzymes, solvents and other treatments on inhibitory activity in ammonium sulfate-precipitated $P$. jensenii B1264 culture supernates were assessed. Treatment with proteinase $\mathrm{K}$, pronase $\mathrm{E}$ or type XIV protease eliminated activity. This data provided further support that the inhibitory activity was a protein or peptide. Treatment with trypsin, $\alpha$-chymotrypsin, type VI-A protease, lysozyme or catalase did not affect activity (table II). Adjusting inhibitory preparations to $\mathrm{pH}$ values ranging from 2.2 to 10.2 or treatments with 0.1 to $1.0 \mathrm{~mol} \cdot \mathrm{L}^{-1} \mathrm{NaCl}$ for up to $225 \mathrm{~min}$ did not affect activity. Inhibitory activity was stable to heating at $100{ }^{\circ} \mathrm{C}$ for 0 to $60 \mathrm{~min}$, treat-

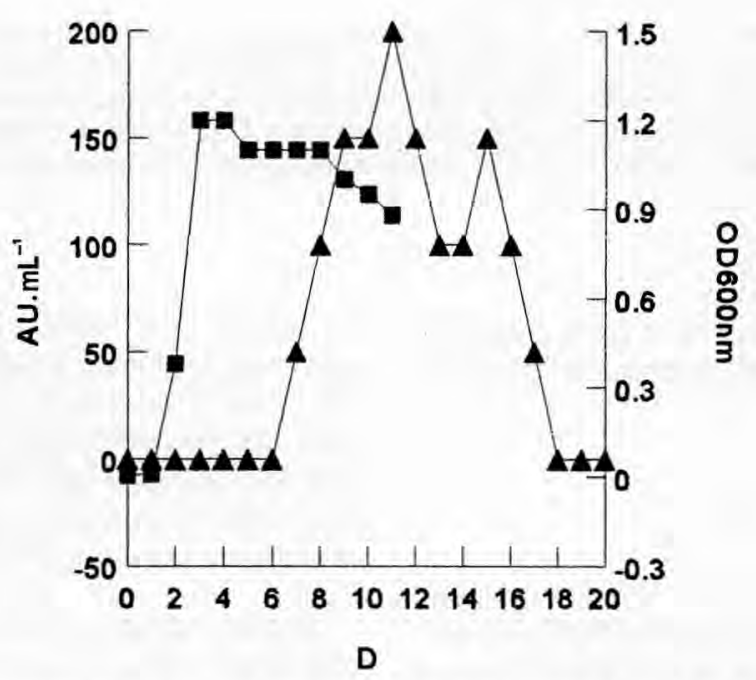

Figure 2. Bacteriocin production by Propionibacterium jensenii B1264. P. jensenii B1264 was propagated in $1 \mathrm{~L}$ sodium lactate broth cultures at $32{ }^{\circ} \mathrm{C}$ for $20 \mathrm{~d}$ under flowing $\mathrm{CO}_{2}\left(0.4 \mathrm{~L} \cdot \mathrm{h}^{-1}\right)$. At daily intervals, $10 \mathrm{~mL}$ sample aliquots were removed and examined for turbidity by determining optical density on a Spectronic 20 at $600 \mathrm{~nm}\left(\mathbf{E}, \mathrm{OD}_{600 \mathrm{~nm}}\right)$. The sample then was centrifuged (1 $300 \mathrm{~g}$ for $15 \mathrm{~min}$ ) and supernatants were filtered through $0.45 \mu \mathrm{m}$ filters and assayed for activity $\left(\boldsymbol{\Delta}, \mathrm{AU} \cdot \mathrm{mL}^{-1}\right)$ against Lactobacillus delbrueckii subsp. lactis ATCC 4797.

Figure 2. Production de bactériocine par Propionibacterium jensenii B1264. P. jensenii B1264 était cultivé dans $1 \mathrm{~L}$ de bouillon de culture au lactate de sodium à $32{ }^{\circ} \mathrm{C}$ pendant $20 \mathrm{j}$ sous flux de $\mathrm{CO}_{2}$ $\left(0,4 \mathrm{~L} \cdot \mathrm{h}^{-1}\right)$. À intervalles journaliers, des échantillons de $10 \mathrm{~mL}$ étaient prélevés et leur turbidité était déterminée par densité optique sur un Spectronic 20 à $600 \mathrm{~nm}\left(\boldsymbol{\nabla}, \mathrm{DO}_{600} \mathrm{~nm}\right)$. L'échantillon était ensuite centrifugé ( $1300 \mathrm{~g}$ - $15 \mathrm{~min}$ ) et les surnageants étaient filtrés sur filtres de $0,45 \mu \mathrm{m}$ et testés pour leur activité $\left(\boldsymbol{\Delta}, \mathrm{UA} \cdot \mathrm{mL}^{-1}\right)$ sur Lactobacillus delbrueckii subsp. lactis ATCC 4797. 


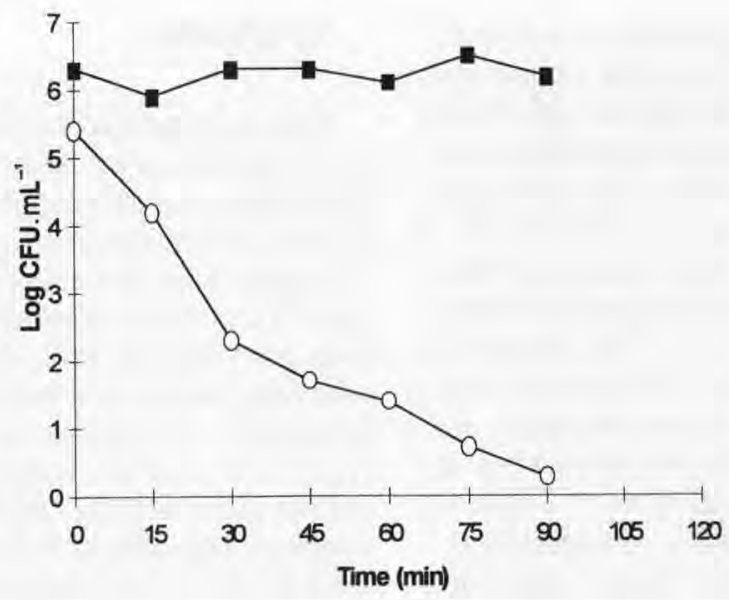

Figure 3. Lethal action of Propionibacterium jensenii B1264 bacteriocin against Lactobacillus delbrueckii subsp. lactis. Crude bacteriocin (O) 4800 total AU; $119.4 \mathrm{AU} \cdot \mathrm{g}^{-1}$ protein) or $0.05 \mathrm{~mol} \cdot \mathrm{L}^{-1}$ phosphate buffer, pH 6.8(-), was added to washed cells of a 20-h MRS broth culture of $\mathrm{Lb}$. delbrueckii subsp. lactis ATCC 4797 in the same buffer and held at $37^{\circ} \mathrm{C}$ for $0,15,30,60$ or $90 \mathrm{~min}$. Culture populations were determined at each interval.

Figure 3. Action létale de la bactériocine de Propionibacterium jensenii B1264 sur Lactobacillus delbrueckii subsp. lactis. La bactériocine brute (O) $4800 \mathrm{UA}$ totale ; 119,4 UA.g-1 de protéine) ou $0,05 \mathrm{~mol} \cdot \mathrm{L}^{-1}$ de tampon phosphate, $\mathrm{pH} 6,8(\boldsymbol{\bullet})$, était ajoutés à des cellules lavées d'une culture sur bouilllon MRS de $20 \mathrm{~h}$ de $\mathrm{Lb}$. delbrueckii subsp. lactis ATCC 4797 dans le même tampon et maintenue à $37^{\circ} \mathrm{C}$ pendant $0,15,30,60$ ou $90 \mathrm{~min}$. Des dénombrements étaient réalisés à chacun de ces temps.

ment with $4 \mathrm{~mol} \cdot \mathrm{L}^{-1}$ urea for $6 \mathrm{~h}$ or addition of SDS at final concentrations of 0.1 to $2.0 \%$.

\subsection{Purification}

Ammonium sulphate ( $80 \%$ saturation) initially was used to concentrate and precipitate the inhibitor produced by $P$. jensenii B1264. To optimize the concentration step, ammonium sulphate was added to separate cell-free supernatants, and pellets were examined for bacteriocin activity. Ammonium sulphate at all concentrations $(40,45$, $50,55,60,65,70$ and $80 \%$ saturation) precipitated activity $(80,160,400,2400,3000$, 3200,3800 and 3800 total AU, respectively). Lowest protein and maximum activity precipitated at $70 \%$ saturation. This concentration of ammonium sulphate was used for further experiments. Resuspension of ammonium sulphate pellets from $16-\mathrm{L}$ cultures into $20 \mathrm{~mL}$ sodium phosphate buffer typically yielded preparations containing $800 \mathrm{AU} \cdot \mathrm{mL}^{-1}$ to $3200 \mathrm{AU} \cdot \mathrm{mL}^{-1}$. Ammonium sulphate-precipitated preparations are hereafter called crude bacteriocin.

In preparation for ion exchange chromatography (IEC), crude bacteriocin was examined by analytical isoelectric focussing (IEF) on a pH 3 to 7 gradient gel (figure 4). The inhibitor remained active throughout focussing, allowing for detection in focussed gels. Inhibition corresponded to a silverstained protein that focussed between $\mathrm{pH} 3$ and 3.5 , indicating that the inhibitor has an isoelectric point (pI) between $\mathrm{pH} 3.0$ and 3.5. The inhibitor was subjected to batch anion exchange chromatography at $\mathrm{pH} 6$; activity was adsorbed to separate batches 
Table II. Enzyme effects on inhibitory activity against Lactobacillus delbrueckii subsp. lactis ATCC 4797.

Tableau II. Effet des enzymes sur l'activité inhibitrice envers Lactobacillus delbrueckii subsp. lactis ATCC 4797.

\begin{tabular}{lccc}
\hline Enzyme $^{a}$ & $\begin{array}{c}\text { Enzyme } \\
\text { treated } \\
\text { inhibitor }\end{array}$ & $\begin{array}{c}\text { Untreated } \\
\text { inhibitor } \\
\text { control }\end{array}$ & $\begin{array}{c}\text { Colony } \\
\text { of } \\
\text { B1264 }\end{array}$ \\
\hline Pronase type XIV & no & yes & no \\
Pronase E & no & yes & no \\
Protease K & no & yes & no \\
$\alpha$-Chymotrypsin & yes & yes & yes \\
Protease type VI-A & yes & yes & yes \\
Trypsin & yes & yes & yes \\
Lysozyme & yes & yes & yes \\
Catalase & yes & yes & yes \\
Distilled water & yes & yes & yes \\
\hline
\end{tabular}

anzymes $\left(15 \mu \mathrm{L}, 10 \mathrm{mg} \cdot \mathrm{mL}^{-1}\right)$ were spotted beside $15 \mu \mathrm{L}$ crude bacteriocin on NLA $\left(119.4 \mathrm{AU} \cdot \mathrm{g}^{-1} \cdot\right.$ protein; dried $^{\circ}$ for $1 \mathrm{~h}$ at $22^{\circ} \mathrm{C}$ ) or beside colonies of $P$. jensenii $\mathrm{B} 1264(5 \mathrm{~d})$ and held for $1 \mathrm{~h}$ at $25^{\circ} \mathrm{C}$ or $37^{\circ} \mathrm{C}$. Plates were then overlaid with soft agar seeded with the sensitive indicator, Lb. delbrueckii subsp. lactis ATCC 4797, and incubated for development of the lawn. ${ }^{b}$ Legend: yes, retains activity after treatment; no, loses activity after treatment.

"Les enzymes $\left(15 \mu \mathrm{L}, 10 \mathrm{mg} \cdot \mathrm{mL}^{-1}\right)$ étaient déposées près de $15 \mu \mathrm{L}$ de bactériocine brute sur agar au lactate de sodium $\left(119,4 \mathrm{UA} \cdot \mathrm{g}^{-1}\right.$ de protéine ; séché 1 h à $\left.22^{\circ} \mathrm{C}\right)$ ou près de colonies de $P$. jensenii B1264 (5 j) et maintenus $1 \mathrm{~h}$ à $25^{\circ} \mathrm{C}$ ou $37^{\circ} \mathrm{C}$. Les boîtes étaient alors recouvertes d'agar contenant la souche indicatrice sensible, Lb. delbrueckii subsp. lactis ATCC 4797, et incubée pour le développement du tapis bactérien. ${ }^{\text {b }}$ Légende : yes, activité conservée après traitement ; no, activité perdue après traitement.

of Bio-Rad Macroprep Q resin. Sodium phosphate buffer containing $0.1,0.3,0.5$, 0.7 or $1 \mathrm{~mol} \cdot \mathrm{L}^{-1}$ sodium chloride was applied to the resin and eluted fractions were assayed for protein and inhibitory activity. All salt concentrations eluted equal activity; an increase in salt concentration eluted increased protein. Therefore, $0.1 \mathrm{~mol} \cdot \mathrm{L}^{-1}$ sodium chloride was selected. Application of $0.1 \mathrm{~mol} \cdot \mathrm{L}^{-1}$ sodium chloride eluted all activity and resulted in $101 \%$ recovery and 15 -fold purification.

The IEC-purified inhibitor was subjected to two-dimensional SDS-PAGE/IEF. Activity migrated on SDS-PAGE gels in one inhibitory zone corresponding to three silverstained protein bands (figure 5). Bands of approximately $6 \mathrm{kDa}$ and $9 \mathrm{kDa}$ migrated at a location corresponding to the centre of the inhibitory zone; an $11-\mathrm{kDa}$ band migrated near the zone periphery. Because diffusion is not unidirectional, activity was most likely not associated with the $11-\mathrm{kDa}$ band; thus it was most likely associated with either or both of the 6- or 9-kDa bands. The portion of the gel corresponding to the inhibition zone was focussed on a $\mathrm{pH} 3$ to 10 gradient IEF gel. Focussing yielded an inhibition zone corresponding to a single silver-staining band migrating between $\mathrm{pH}$ 3 and 3.5 confirming the $\mathrm{pI}$ (data not shown). A faint band focussing near $\mathrm{pH} 4.5$ was not associated with activity. The results suggested that bacteriocin activity produced by $P$. jensenii $\mathrm{B} 1264$ may be due to one agent.

\section{DISCUSSION}

Eight out of thirteen propionibacteria produced bacteriocins, i.e. protease-sensitive, catalase-insensitive agents that inhibited 

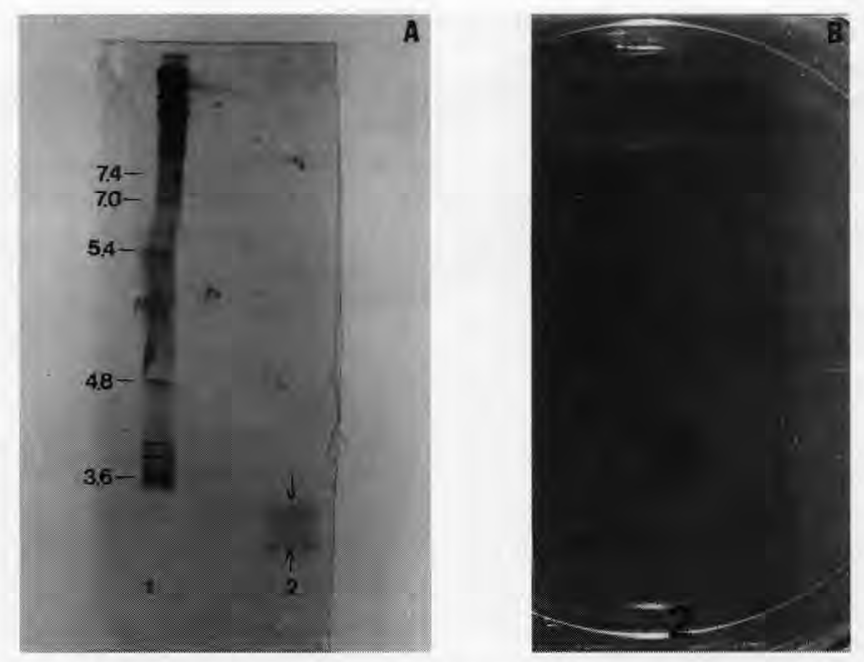

Figure 4. Analytical isoelectric focussing of bacteriocin. Crude bacteriocin $\left(25 \mu \mathrm{L}, 6400 \mathrm{AU} \cdot \mathrm{mL}^{-1}\right.$, $1.9 \mathrm{mg}$ protein per $\mathrm{mL}$ ) was focussed on a $\mathrm{pH} 3$ to 7 gradient agarose isoelectric focussing (IEF) gel for 45 min at $1500 \mathrm{~V}$. A. Silver-stained gel; B. gel overlaid with Lb. delbrueckii subsp. lactis ATCC 4797 for detection of activity. Lane 1, IEF standards; lane 2, crude bacteriocin.

Figure 4. Analyse par focalisation isoélectrique de bactériocine. La bactériocine brute $(25 \mu \mathrm{L}, 6800$ UA. $\mathrm{mg}^{-1}, 1,9 \mathrm{mg}$ de protéine par $\mathrm{mL}$ ) était observée sur 1 gel d'agarose pour focalisation isoélectrique (IEF) de gradient de $\mathrm{pH}$ de 3 à 7 , pendant 45 min à $1500 \mathrm{~V}$. A. gel coloré à l'argent. B. gel recouvert de $L b$. delbrueckii subsp. lactis ATCC 4797 pour détection de l'activité. ligne 1, standards IEF ; ligne 2, bactériocine brute.

closely related species. Bacteriocin production may be as common in propionibacteria as it is in other species.

The antagonist produced by $P$. jensenii B1264 was selected for further study and its partial purification and characterization is described. The inhibitor is proteinaceous in nature, has a narrow inhibitory spectrum and a bactericidal mode of action and thus meets the classical criterion for bacteriocins [18]. Its activity spectrum differs from those of propionicin PLG-1 and jenseniin G. Unlike propionicin PLG-1 [11], it inhibits $P$. thoenii P127 and does not inhibit Gram-negative species. Unlike jenseniin G [6], it inhibits the jenseniin $G$ producer P. thoenii (jensenii) P126, Lb. acidophilus ATCC 4356 and $L b$. casei ATCC 7469. It is more heat-stable $\left(100{ }^{\circ} \mathrm{C}\right.$ for $60 \mathrm{~min}$ ) than propionicin PLG-1 $\left(\leq 85^{\circ} \mathrm{C}\right)[12]$ and jenseniin $\mathrm{G}\left(100^{\circ} \mathrm{C}, 15\right.$ min) [6]. In contrast to jenseniin $\mathrm{G}$ (pI between 11 and 11.5; unpublished data), propionicin PLG-1 (pI of 8.8) [12] and most other characterized bacteriocins, it is an acidic bacteriocin with a pI between 3 and 3.5. It is smaller (estimated molecular mass of 6 to $9 \mathrm{kDa}$ ) than propionicin PLG-1 (9 $328 \mathrm{Da}$ ) [15]. The bacteriocin shares some characteristics with the two previously identified bacteriocins from dairy propionibacteria. Like propionicin PLG-1 (pH 3-9) [11] and jenseniin $\mathrm{G}$ ( $\mathrm{pH} 3-12$; unpublished data), it is stable to a wide range of $\mathrm{pH}(\mathrm{pH}$ 3-12). Like propionicin PLG-1 $[9,12]$ and jenseniin $G$ [6], it is produced in late stationary phase producer cultures and the culture supernatant must be concentrated to detect activity.

Although the bacteriocin was not purified to homogeneity, two purification steps were successful in separating it from most contaminating proteins. Ammonium sulfate 

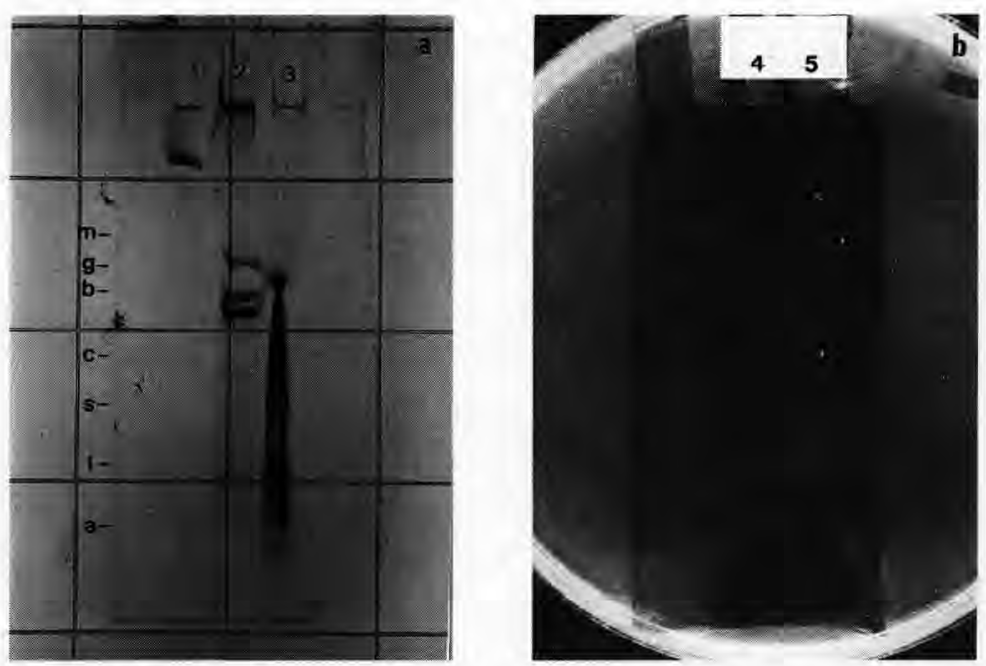

Figure 5. SDS-PAGE of crude and partially-purified bacteriocin. a. Silver-stained SDS-PAGE gel. b. Gel overlaid with $L b$. delbrueckii subsp. lactis ATCC 4797 for detection of activity. Lane 1, prestained Bio-Rad Kaleidoscope Standards (m, myosin, 204 kDa; g, $\beta$-galactosidase, 121 kDa; b, BSA, $78 \mathrm{kDa}$; , carbonic anhydrase, $39.5 \mathrm{kDa}$; s, soybean trypsin inhibitor 30.7, kDa; 1, lysozyme, $19.7 \mathrm{kDa}$; a, aprotinin, $7.7 \mathrm{kDa}$ ). Lanes 3 and $5,15 \mu \mathrm{L}$ crude bacteriocin (6 $400 \mathrm{AU} \cdot \mathrm{mL}^{-1}, 1.9 \mathrm{mg}$ protein per $\mathrm{mL}$ ); lanes 2 and $4,15 \mu \mathrm{L}$ IEC-purified bacteriocin ( $800 \mathrm{AU} \cdot \mathrm{mL}^{-1}, 0.1 \mathrm{mg}$ protein per $\mathrm{mL}$ ).

Figure 5. Analyse par SDS-PAGE de bactériocine brute ou partiellement purifiée. a. Gel SDSPAGE coloré à l'argent. b. Gel recouvert de Lb. delbrueckii subsp. lactis ATCC 4797 pour détection de l'activité. ligne 1, standards Bio-Rad Kaleidoscope pré-colorés (m, myosine, 204 kDa ; g, $\beta$-galactosidase, $121 \mathrm{kDa}$; b, BSA, $78 \mathrm{kDa}$; c, anhydrase carbonique, $39,5 \mathrm{kDA}$; s, inhibiteur trypsique de soja, $30,7 \mathrm{kDa}$; 1, lysozyme, $19,7 \mathrm{kDa}$; a, apoprotéine, 7,7 kDa). lignes 3 et $5,15 \mu \mathrm{L}$ de bactériocine brute (6 $400 \mathrm{UA} \cdot \mathrm{mL}^{-1}, 1,9 \mathrm{mg}$ de protéine par $\left.\mathrm{mL}\right)$; lignes 2 et $4,15 \mu \mathrm{L}$ de bactériocine purifiée par IEF (800 UA. $\mathrm{mL}^{-1}, 0,1 \mathrm{mg}$ de protéine par $\mathrm{mL}$ ).

precipitation followed by batch anion exchange chromatography was optimized to give maximum recovery and greatest purity. Large quantities of the bacteriocin are needed for further purification and other studies. Because 20- to 50-fold concentrated supernatants are required to detect activity in producer cultures, it is produced in minute concentrations. It will be necessary to identify factors supporting its maximum production by $P$. jensenii B1264. Bacteriocins from dairy propionibacteria typically have been examined for use as food preservatives $[13,19]$. The narrow inhibitory spectrum of this bacteriocin limits its application in foods. Its stability to temperature, solvents, $\mathrm{pH}$, salts, and detergents are useful characteristics in industrial applications. Its use for pharmaceutical purposes is currently being explored.

\section{REFERENCES}

[1] Barefoot S.F., Klaenhammer T.R., Purification and characterization of the Lactobacillus acidophilus bacteriocin, lactacin B, Antimicrob. Agents Chemother. 26 (1984) 328-334.

[2] Bradford M.M., A rapid and sensitive method for quantitation of microgram quantities of protein utilizing the principle of dye binding, Anal. Biochem. 72 (1976) 248-254.

[3] Cummins C.S., Johnson J.L., Propionibacterium, in: Sneath P.H.A., Mair N.S., Sharpe M.E., Holt J.G. (Eds.), Bergey's Manual of Systematic Bacteriology, vol. 2, Williams and Wilkins Co., Baltimore, 1986, pp.1346-1353.

[4] Ekinci F.Y., Maximizing production of the Propionibacterium bacteriocin jenseniin G, M.Sc. thesis, Clemson University, Clemson, SC, 1997. 
[5] Garfin D.E., Isoelectric focussing, in: Deutscher M.P. (Ed.), Methods in Enzymology, vol. 182, Guide to Protein Purification, Academic Press, San Diego, 1990, pp. 459-477.

[6] Grinstead D.A., Barefoot S.F., Jenseniin G, a heat-stable bacteriocin produced by Propionibacterium jensenii P 126, Appl. Environ. Microbiol. 58 (1992) 215-220.

[7] Hofherr L.A., Glatz B.A., Hammond E.G., Mutagenesis of strains of Propionibacterium to produce cold sensitive mutants, J. Dairy Sci. 66 (1983) 2482-2487.

[8] Hoover D.G., Harlander S.K., Screening methods for detecting bacteriocin activity, in: Hoover D.G., Steenson L.R. (Eds.), Bacteriocins of Lactic Acid Bacteria, Academic Press, New York, 1993, pp. 23-39.

[9] Hsieh H.Y., Paik H.D., Glatz B.A., Improvement of detection and production of propionicin PLG-1, a bacteriocin produced by Propionibacterium thoenii, J. Food Protect. 59 (1996) $734-738$.

[10] Laemmli U.K., Cleavage of structural proteins during the assembly of the head of bacteriophage T4, Nature 227 (1970) 680-685.

[11] Lyon W.L., Glatz B.A., Partial purification of a bacteriocin produced by Propionibacterium thoenii, Appl. Environ. Microbiol. 57 (1991) 701-706.

[12] Lyon W.L., Glatz B.A., Isolation and purification of propionicin PLG-1, a bacteriocin pro- duced by a strain of Propionibacterium thoenii, Appl. Environ. Microbiol. 59 (1993) 83-88.

[13] Lyon W.L., Sethi J.K., Glatz B.A., Inhibition of psychrotrophic organisms by propionicin PLG-1, a bacteriocin produced by Propionibacterium thoenii, J. Dairy Sci. 76 (1993) 1506-1513.

[14] Muriana P.M., Klaenhammer T.R., Conjugal transfer of plasmid-encoded determinants for bacteriocin production and immunity in Lactobacillus acidophilus 88, Appl. Environ. Microbiol. 53 (1987) 553-560.

[15] Paik H.D., Glatz B.A., Purification and partial amino acid sequence of propionicin PLG-1, a bacteriocin produced by Propionibacterium thoenii P127, Lait 75 (1995) 367-377.

[16] Paik H.D., Glatz B.A., Enhanced bacteriocin production by Propionibacterium thoenii in fedbatch fermentation, J. Food Protect. 75 (1997) 1529-1533.

[17] Stoscheck C.M., Quantitation of protein, in: Deutscher M.P. (Ed.), Methods in Enzymology, vol. 182, Guide to Protein Purification, Academic Press, San Diego, 1990, pp. 50-68.

[18] Tagg J.R., Dajani A.S., Wannamaker L.W., Bacteriocins of Gram-positive bacteria, Bacteriol. Rev. 40 (1976) 722-756.

[19] Weinbrenner D.R., Barefoot S.F., Grinstead D.A., Inhibition of yogurt starter cultures by jenseniin G, a Propionibacterium bacteriocin, J. Dairy Sci. 80 (1997) 1246-1253. 